\title{
Comparative study of semiconductor power losses between CSI-based STATCOM and VSI-based STATCOM, both used for unbalance compensation
}

\author{
Anas Benslimane ${ }^{1 *}$ D, Jamal Bouchnaif ${ }^{2}$, Mohammed Essoufi ${ }^{1}$, Bekkay Hajji ${ }^{1}$ and Loukmane el Idrissi ${ }^{2}$
}

\begin{abstract}
In this paper, we present a detailed procedure to determine the semiconductor losses for both structures of a shunt STATCOM (Static Compensator), STATCOM based on Current Source Inverter (CSI) and STATCOM based on Voltage Source Inverter (VSI), both used for voltage unbalance compensation. As a first step, we study the VSI-based STATCOM and the CSI-based STATCOM used in high speed railway substations. Then we analyze the design and the sizing of the unbalance compensator in order to obtain an unbalance factor that does not exceed the limits imposed by the standards or by the energy provider. Following that, we compare the performances obtained with both structures VSI-STATCOM and CSI-STATCOM, after calculating the semiconductor power losses in the STATCOM converters. Finally, we validate our approach by simulation over real data of unbalance compensation caused by the new high-speed railway in Morocco. We use the tools MATLAB / Simulink/Simpowersys for performing our simulations.
\end{abstract}

Keywords: Power losses, VSI, CSI, STATCOM, Unbalance compensation, Railway

\section{Introduction}

The flexible alternative current transmission system (FACTS) is used in the power grid in order to improve the quality of energy. In particular, the static shunt compensators with voltage source inverters are installed in high-speed railway substations to compensate the unbalance [1-3].

The railway operator is mainly interested in reducing the compensator size, cost, and the converter losses; this is from where comes our idea to propose a replacement of the voltage source inverter structure by the current source inverter structure. To validate this proposition, we show the performances obtained by a CSI-based STATCOM used in the unbalance compensation. The rest of this paper is organized as follows:

\footnotetext{
* Correspondence: anas.benslimane@gmail.com

'Laboratory Renewable energy, embedded system and information processing, National School of Applied Sciences, University of Mohammed I, Oujda, Morocco

Full list of author information is available at the end of the article
}

In the second section, we give an overview of the principle of electric power supply system for high-speed railways (HSR). The third section presents the analysis of voltage unbalance generated by the railway substation. In the fourth section, we present the STATCOM structure used for unbalance compensation. While in the fifth section, we present our sizing methodology and our control strategy, for both STATCOM structure VSI and CSI. The sixth section, we show the detailed calculation of the semiconductor power losses in the converters. Then in the seventh section, we compare and discuss the obtained results for both structures (VSI-based STATCOM and CSI- based STATCOM) using data coming from railway operator in Morocco about the HSR substation.

\section{Principle of electrification of high-speed railway} The HSR are electrified by a tow-phases system $2 * 25 \mathrm{KV}$ $-50 \mathrm{~Hz}$ (Fig. 1), where the single-phase transformer of the substation is connected between two phases of the HV power grid. 


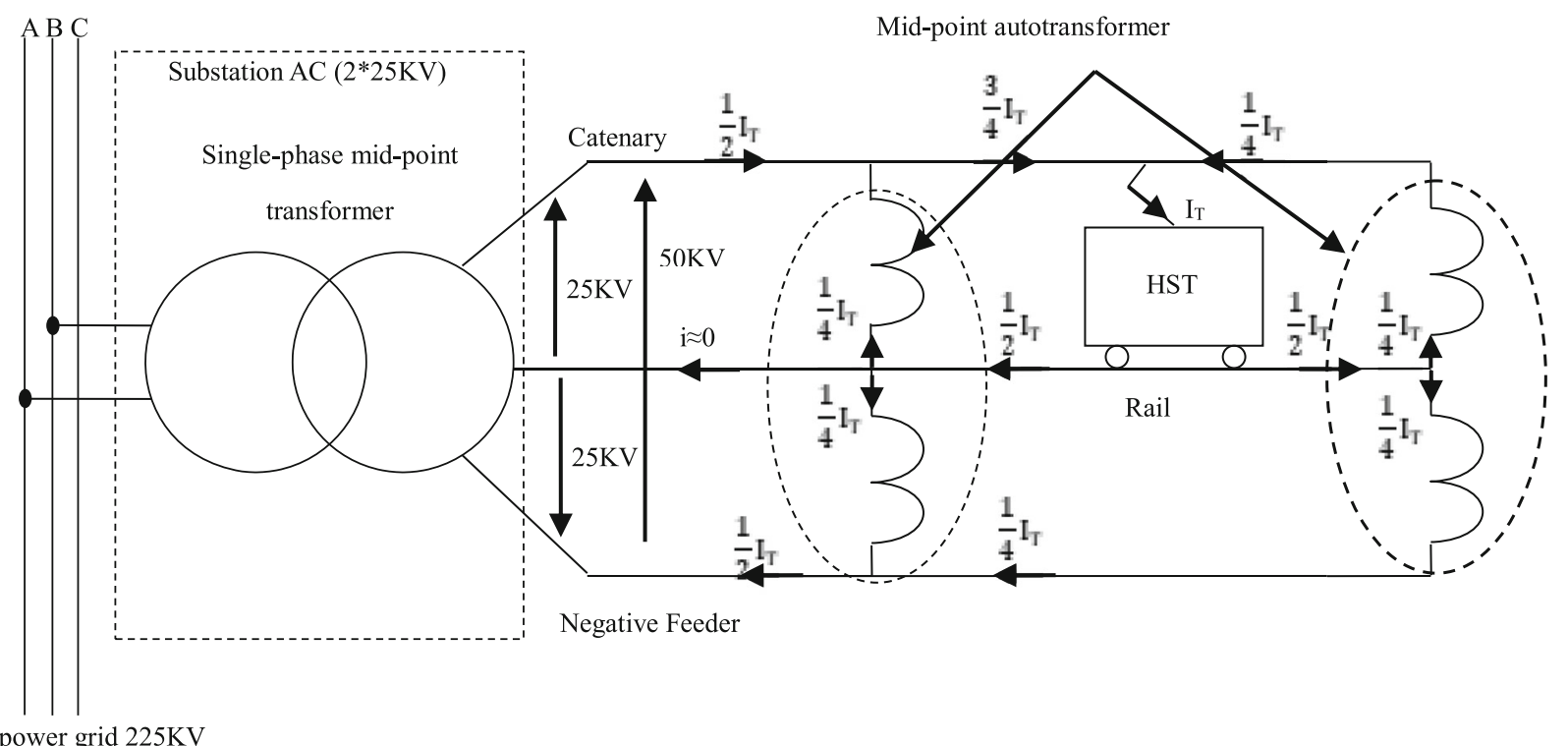

HV power grid $225 \mathrm{KV}$

Fig. 1 Power circuit of supply AC system $\left(2^{*} 25 \mathrm{KV}-50 \mathrm{~Hz}\right)$ of the HSR substation

This system transmits the energy at $50 \mathrm{kV}$ between the catenary and a complementary cable, called the "negative feeder". A voltage of $25 \mathrm{kV}$ between the catenary and the railis, is obtained by means of Mid-point autotransformer connected between the catenary, the rail, and the negative feeder. The first implementation of this solution was in 1981 on the HST South-East line in France [2].

\section{Analysis of the unbalance caused by HSR}

A three-phase system is balanced if the three currents or voltages have the same amplitude, the same frequency, as well as the difference between their phases is equal to $120^{\circ}$; otherwise the system is unbalanced. The HSR substations generate a significant unbalance in the high voltage lines with low short-circuit power $\left(\mathbf{S}_{\mathbf{c c}}\right)$, because they are more sensitive to the disruptions. Figure 2 shows the supply schema of a HSR substation by a three-phase line with line impedance $\left(\mathbf{Z}_{\mathbf{c c}}\right)$ [2].
The apparent power and the unbalance factor for HSR substations:

$$
\begin{aligned}
& T_{i V}(\%) \approx 100 \frac{S_{s s}}{S_{C C}} \\
& S_{s s}=U \cdot I_{S S}
\end{aligned}
$$

\section{Compensation of the unbalance by STATCOM}

\subsection{Principle of the STATCOM}

The static compensator (as shown in Fig. 3) is a threephase sinusoidal AC current source that injects the negative sequence of currents to compensate the unbalance at the PCC point. This injection of current is made by the STATCOM which is based on power electronics converters $[2-4,5,6]$.

The STATCOM must be sized to control the unbalance around $\mathrm{T}_{\mathrm{iv} \cdot \max }$ in the limit imposed by the energy

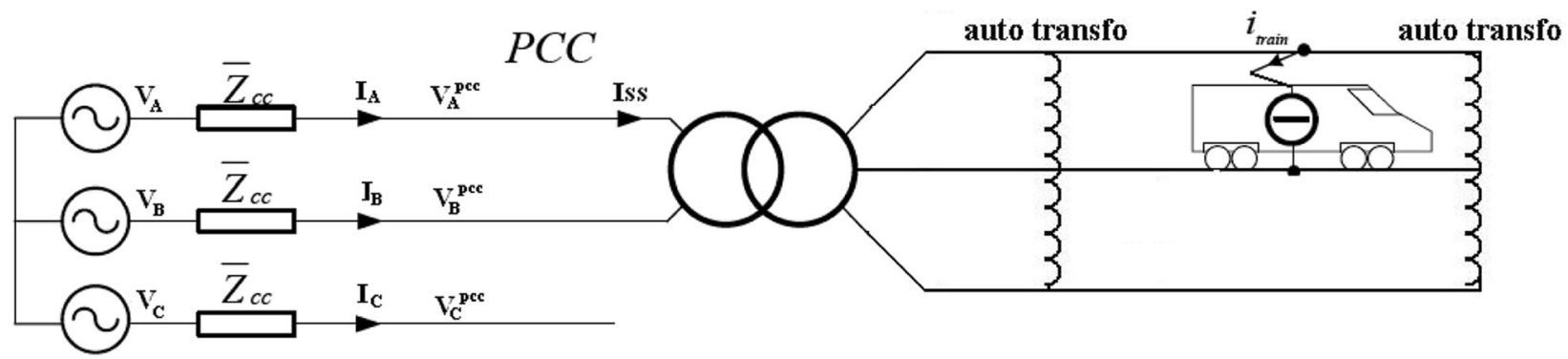

Fig. 2 A power schema of a substation connection [2] 


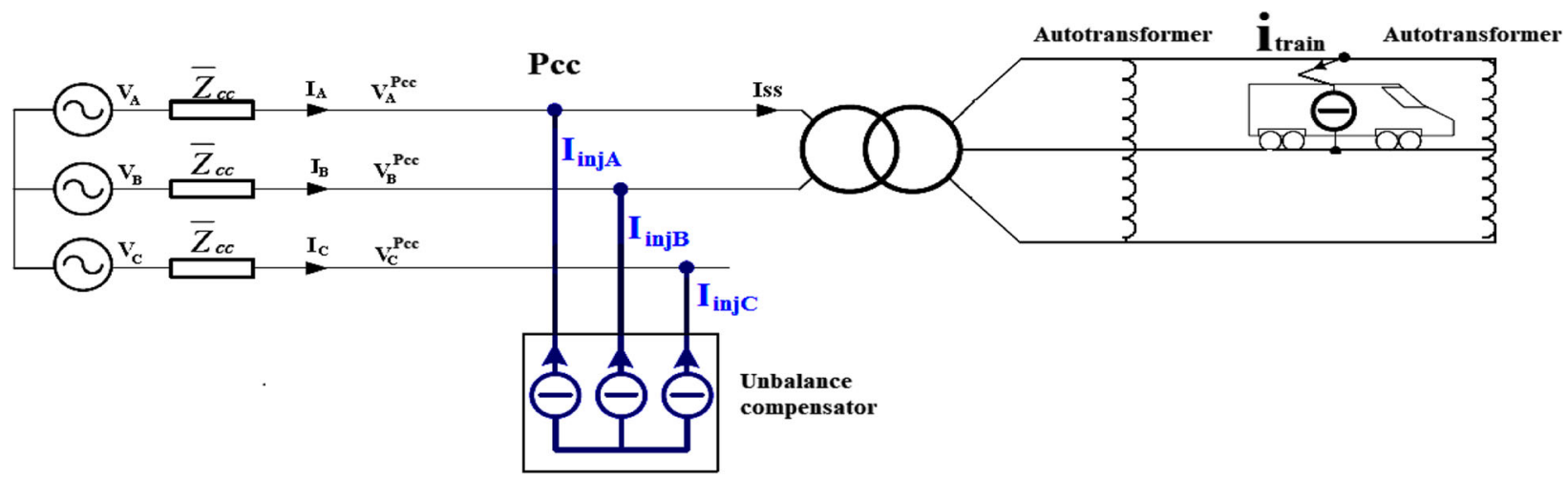

Fig. 3 Diagram of an unbalance compensator

provider. The currents injected at PCC have a negative sequence [7] (see Table 1).

- For total compensation:

$$
\overline{I_{i n j}^{-}}=\frac{\sqrt{3}}{3} \overline{I_{S S}} e^{j \frac{\pi}{6}}
$$

The apparent power of STATCOM used for unbalance total compensation is: [7].

$$
S_{C . T o t a l}=\sqrt{3} U I_{i n j}^{-}=\sqrt{3} U \frac{\sqrt{3}}{3} I_{S S}=U I_{S S}=S_{S S}
$$

\section{- For partial compensation:}

In order to size the STATCOM, in first step, it is necessary to determine the percentage of the limit RMS value of the current negative component to be injected:

$$
I_{i n j}^{-}(\%)=T_{i V \cdot \max }(\%) \cdot \frac{S_{C C}}{\sqrt{3} U} \cdot \frac{1}{100}
$$

The apparent power of STATCOM used for unbalance partial compensation is given by:

$$
S_{\text {C.partial }}=\frac{I_{\text {inj }}^{-}(\%)}{100} \cdot S_{s s}
$$

\subsection{Voltage source inverter based STATCOM (VSI- STATCOM)}

A compensator STATCOM based on a VSI (see Fig. 4) is composed of several compensation cells coupled in parallel with the secondary of the three-phase transformer with $\mathrm{Yy0}$ connection. Each cell contains an $\mathrm{AC}$ filter inductor (L), a VSI converter with sine-triangle PWM control, and a DC side voltage source made by a capacitor $\left(\mathrm{C}_{\mathrm{dc}}\right)$. The VSI-STATCOM and the HSR substation (unbalanced load) are connected to the PCC bus

In general, the apparent power of the compensator $\left(\mathrm{S}_{\mathrm{c}}\right)$ is equal to the number of cells $\left(\mathrm{N}_{\mathrm{VSI}}\right)$ multiplied by the power of each cell $\left(\mathrm{S}_{\text {cel }}\right)$ :

Table 1 Expression \& diagram of injected currents

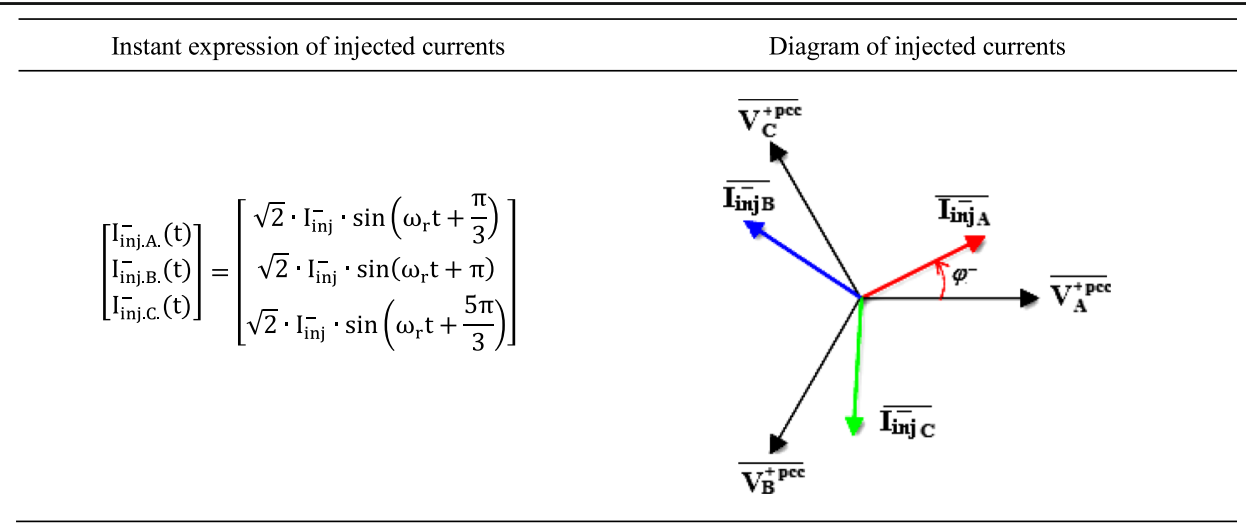


Table 2 Expression of Peak, RMS, and AVG value of IGBT and antiparallel diode current and voltage (VSI cell)

\begin{tabular}{lllll}
\hline & Peak current expression & RMS current expression & AVG current expression & DC Voltage expression \\
\hline IGBT & $\sqrt{2} \cdot \mathrm{l}_{\text {inj }}$ & $\mathrm{I}_{\text {inj }}\left(0,18 r_{\max }+0,5\right)$ & $\mathrm{I}_{\text {inj }}\left(0,18 r_{\text {max }}+0,22\right)$ & $V_{D C \text {. ref }}$ \\
Anti-parallel diode & $\sqrt{2} \cdot l_{\text {inj }}$ & $I_{\text {inj }}\left(0,5-0,3 r_{\text {max }}\right)$ & $I_{\text {inj }}\left(0,22-0,18 r_{\text {max }}\right)$ & $V_{D C \text {. ref }}$ \\
\hline
\end{tabular}

$$
S_{C}=N_{V S I} \cdot S_{c e l}
$$

$$
S_{C}=N_{C S I} \cdot S_{c e l}
$$

\subsection{Current source inverter based STATCOM}

A CSI-STATCOM (see Fig. 5) is composed of several compensation cells coupled in parallel to the secondary of the three-phase transformer with $\mathrm{Yy0}$ connection. Each cell contains an AC LC filter, a CSI converter with sine-triangle PWM control, and a DC side current source realized by an inductor $\left(\mathrm{L}_{\mathrm{dc}}\right)$. The CSISTATCOM and the HSR substation (unbalanced load) are connected to the PCC bus.

In general, the apparent power of compensator $\left(\mathrm{S}_{\mathrm{c}}\right.$. $)$ is equal to the number of cells $\left(\mathrm{N}_{\mathrm{CSI}}\right)$ multiplied by the power of each cell $\left(\mathrm{S}_{\mathrm{cel}}\right)$ :

\section{Sizing and control strategy of STATCOM 5.1 Sizing of VSI-STATCOM cell}

The power circuit of the VSI-STATCOM cell is composed of a six bidirectional current switch (IGBT with anti-parallel diode), a capacitive storage source in a DC side inverter, and a three-phase inductor filter connected between the AC side inverter $\left(a^{\prime}, b^{\prime}, c^{\prime}\right)$ and the transformer secondary $(\mathrm{a}, \mathrm{b}, \mathrm{c})$. The IGBT switch is controlled by the PWM signal (see Fig. 6).

The DC capacitor and the filter inductor are given by the flowing expressions [8-10]:

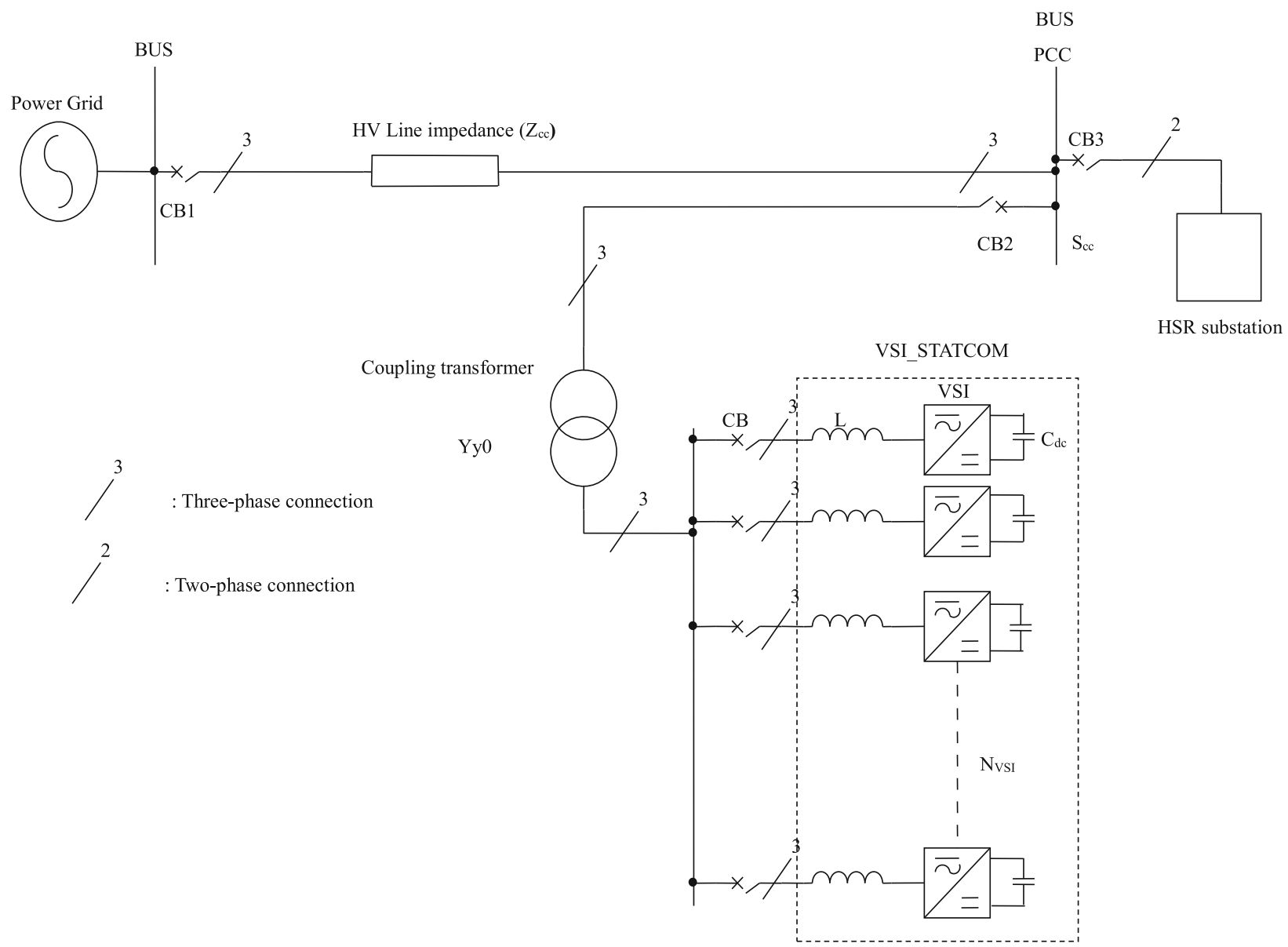

Fig. 4 One-Line Diagram of VSI-STATCOM 


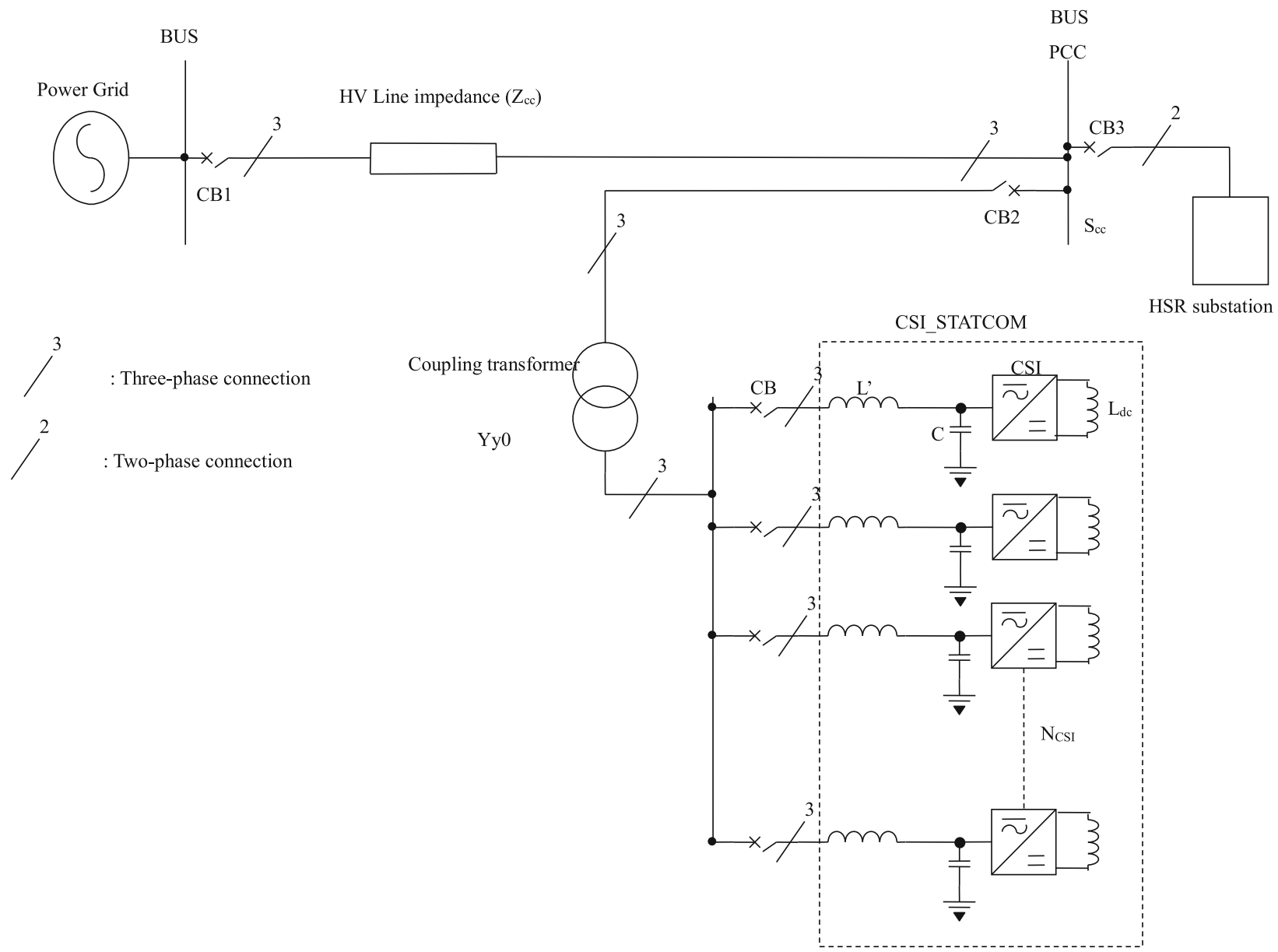

Fig. 5 One-Line Diagram of CSI-STATCOM

$$
\begin{aligned}
& C_{d c}=\frac{\sqrt{2} \cdot S_{c e l}}{V_{D C . r e f} \cdot \Delta V_{D C}(\max ) \cdot \omega_{r}} \\
& L=\frac{V_{D C . r e f}}{12 \cdot f_{d} \cdot \Delta I_{i n j}}
\end{aligned}
$$

The voltage and current supported by IGBT are given by the flowing expressions [11]:

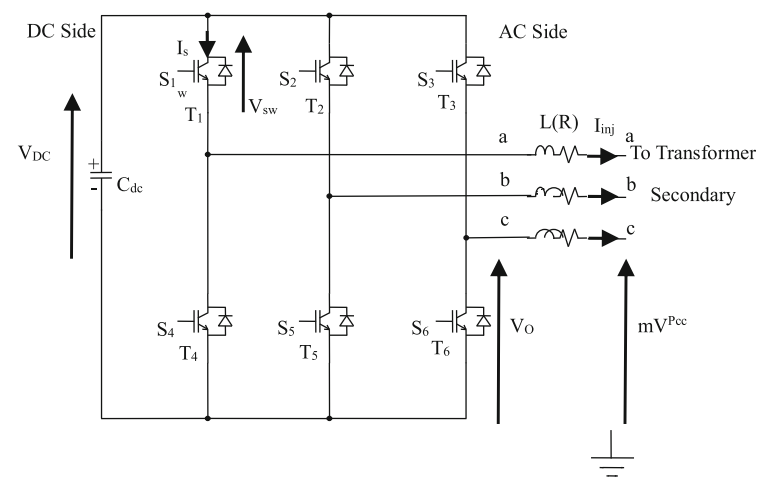

Fig. 6 Power circuit of VSI-STATCOM cell

$$
\begin{aligned}
& I_{s w} \geq \sqrt{2} \cdot I_{i n j} \\
& V_{s w} \geq V_{D C . r e f}
\end{aligned}
$$

The VSI_STATCOM cell apparent power is given by:

$$
S_{c e l}=3 \cdot m V^{p c c} \cdot I_{i n j}
$$

\subsection{Sizing of the CSI-STATCOM cell}

The power circuit of the CSI-STATCOM cell is composed of six unidirectional current switches (only IGBT or IGBT with anti-parallel diode and diode in series), an inductor storage source in the DC side inverter, and a three-phase L'C filter connected between the AC side inverter ( $\left.a^{\prime}, b^{\prime}, c^{\prime}\right)$ and the transformer secondary $(\mathrm{a}, \mathrm{b}, \mathrm{c})$. The IGBT switches are controlled by the PWM signal (see Fig. 7).

The DC inductor and the L'C filter are given by the flowing expressions: [12].

$$
L_{d c}=\frac{\sqrt{2} \cdot S_{c e l}\left(1-\left(2 \cdot C \cdot \omega_{r}^{2} \cdot L^{\prime}\right)\right)}{I_{D C \cdot r e f} \cdot \Delta I_{D C}(\max ) \cdot \omega_{r}}
$$




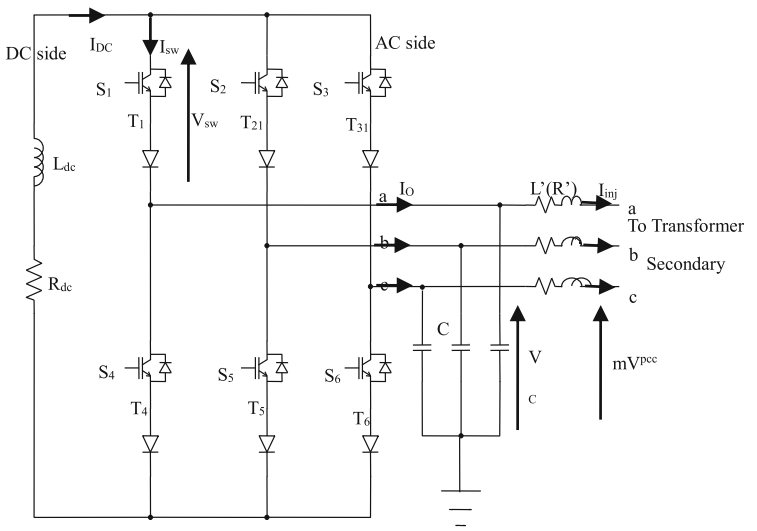

Fig. 7 Power circuit of CSI_STATCOM cell

$$
\begin{aligned}
& L^{\prime}=\frac{\left(m V^{p c c}\right)^{2}}{3 \cdot S_{c e l} \cdot \omega_{r}} \\
& C=\frac{1}{L^{\prime} \cdot \omega_{0}^{2}}
\end{aligned}
$$

The voltage and current supported by IGBT are given by the flowing expressions: [11].

$$
\begin{aligned}
& I_{s w} \geq I_{D C . r e f} \\
& V_{s w} \geq \sqrt{2} \cdot V_{C}(\max )
\end{aligned}
$$

The CSI-STATCOM cell apparent power is given by:

$$
S_{c e l}=3 \cdot m V^{p c c} \cdot I_{i n j}
$$

The fundamental component of the $\mathrm{AC}$ side current $\left(\mathrm{I}_{\mathrm{O}}\right)$ is given by: [12].

$$
\begin{aligned}
& I_{D C \cdot r \mathrm{e}^{\prime} f=\sqrt{2} \cdot I_{O}(\max )}(20) \\
& \overline{I_{O}}=\overline{I_{i n j}}\left(1-C \cdot L^{\prime} \cdot \omega_{r}{ }^{2}\right)+j \cdot C \cdot \omega_{r} \cdot m \overline{V^{p c c}}
\end{aligned}
$$

\subsection{Control of VSI_STATCOM cell}

The shunt STATCOM must inject the negative sequence of the current consumed by the single-phase load (High speed railway substation) in the transformer's secondary. According to equations of Table 1, the block diagram for the set-point generation of the injected currents is shown in Fig. $8[9,13]$.

The VSI-STATCOM cell is controlled by two loops: The first loop controls the injected current $\left(\mathrm{I}_{\text {inj }}\right)$ in the d-q plan (park transformation) with PI controller $R_{I}(p)$ (see Fig. 9), the second loop regulates the DC bus voltage $\left(\mathrm{V}_{\mathrm{dc}}\right)$ around its reference value with a proportional delay controller $R_{u}(p)$ (see Fig. 10). The generation of three-phase PWM control signals from the corrected sinusoidal modulating signals (sine) is shown in Fig. 11.

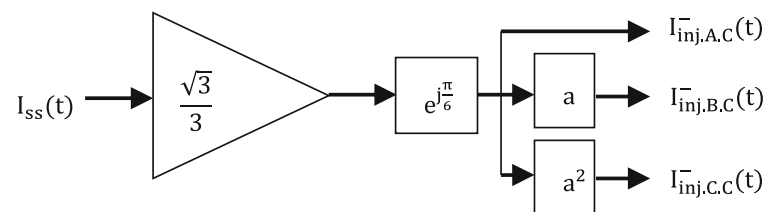

Fig. 8 Obtaining the set-point currents to be injected

The transfer functions of controllers used in the control part are given by [9]:

$$
\begin{aligned}
& R_{u}(p)=\frac{K_{v}}{1+\tau_{v} p} \\
& R_{I}(p)=K_{I} \frac{1+\tau_{I} p}{\tau_{I} p}
\end{aligned}
$$

The transformation matrices (Park \& Clark) are given by:

$$
\begin{aligned}
C & =\frac{1}{\sqrt{3}}\left[\begin{array}{ccc}
0 & \frac{\sqrt{3}}{\sqrt{2}} & \frac{-\sqrt{3}}{\sqrt{2}} \\
\sqrt{2} & \frac{-1}{\sqrt{2}} & \frac{-1}{\sqrt{2}}
\end{array}\right] \text { And } C^{\prime} \\
& =\left[\begin{array}{cc}
V_{\alpha} & V_{\beta} \\
-V_{\beta} & V_{\alpha}
\end{array}\right]
\end{aligned}
$$

$$
\left\{P_{k}^{-}=\frac{1}{3}\left[\begin{array}{ccc}
2 \sin (-\theta) & 2 \sin \left(-\theta-\frac{2 \pi}{3}\right) & 2 \sin \left(-\theta+\frac{2 \pi}{3}\right) \\
2 \cos (-\theta) & 2 \cos \left(-\theta-\frac{2 \pi}{3}\right) & 2 \cos \left(-\theta+\frac{2 \pi}{3}\right) \\
1 & \theta=\omega_{r} \cdot t & 1
\end{array}\right]\right.
$$

\subsection{Control of CSI-STATCOM cell}

The CSI-STATCOM cell is controlled by two loops: The first loop controls the injected current $\left(\mathrm{I}_{\text {inj }}\right)$ in the d-q plan (park transformation) with PID controller $\mathrm{R}_{\mathrm{I} 1}$ (p) (see Fig. 12); the second loop regulates the DC bus current $\left(\mathrm{I}_{\mathrm{DC}}\right)$ around its reference value with a proportional delay controller $\mathrm{R}_{\mathrm{I} 2}(\mathrm{p})$ (Fig. 13). We use the same block diagrams (Figs. 8 and 11) for the injection of set-point currents and the generation of three-phases PWM signals,

The transfer functions of controllers used in the control part are given by [12]:

$$
\begin{aligned}
& R_{I 1}(p)=K_{I}^{\prime} \frac{1+\tau_{I}^{\prime} p+\tau_{I}^{\prime} \tau_{d} p^{2}}{\tau_{I}^{\prime} p} \\
& R_{I 2}(p)=\frac{K_{I D C}}{1+\tau_{I D C} S}
\end{aligned}
$$




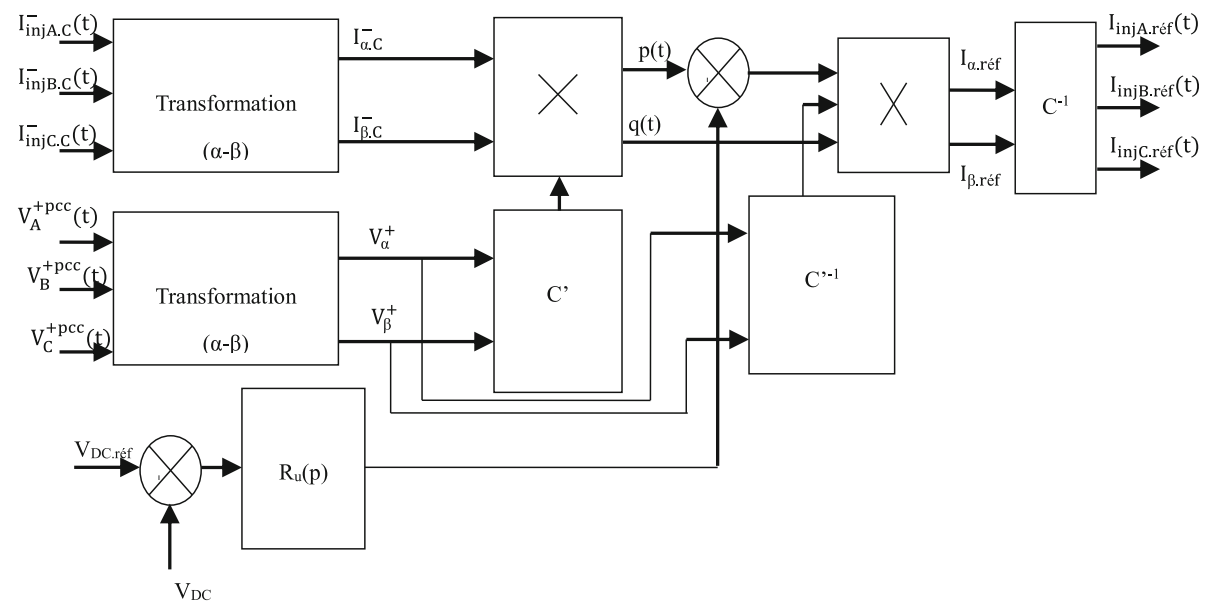

Fig. 9 Diagram control blocks of the voltage $V_{D C}$

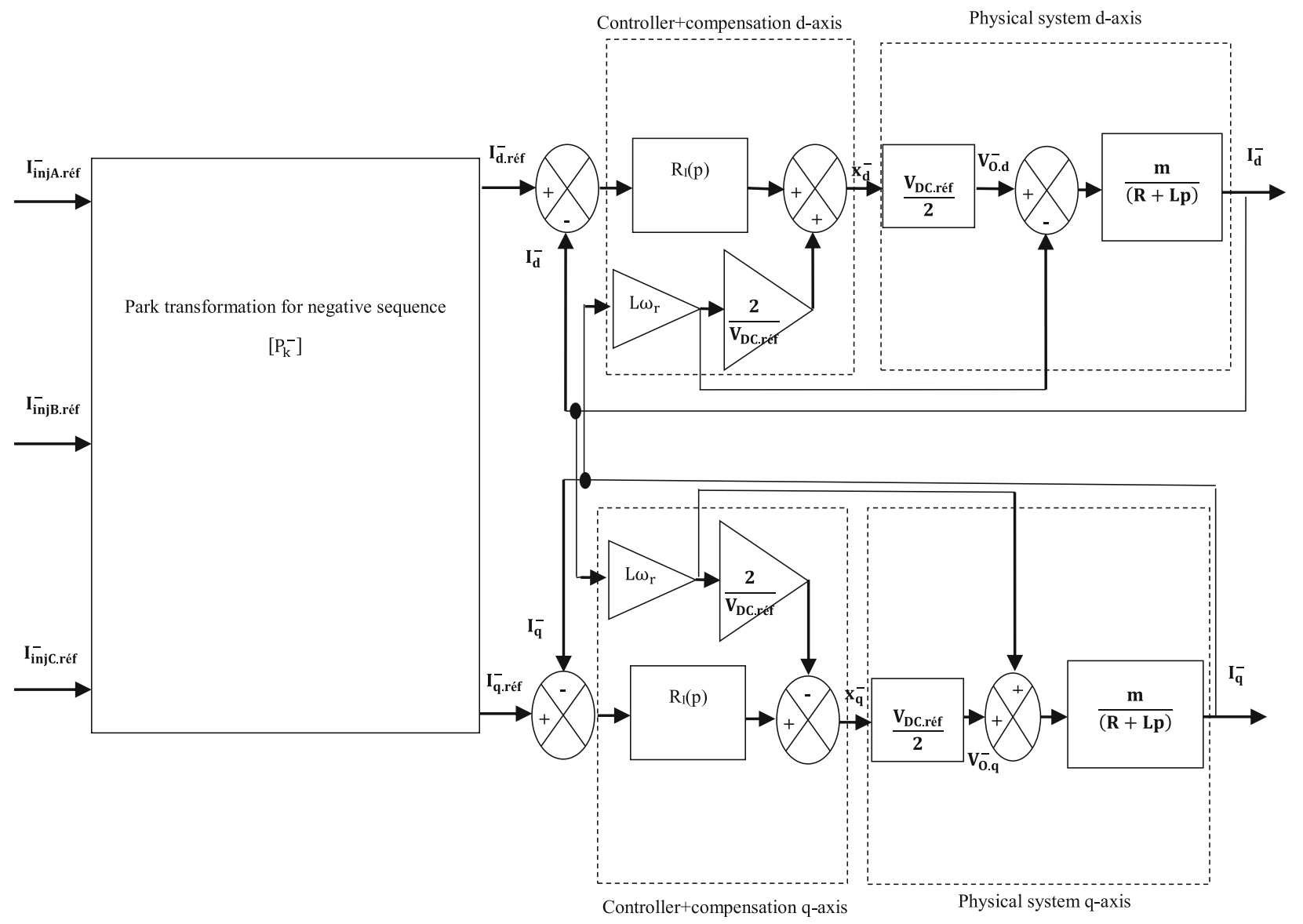

Fig. 10 Diagram control blocks of the injected current negative sequence for VSI cell 
The transfer functions of the physical system for CSISTATCOM in dq plan are given by [12]:

$$
\begin{aligned}
& H_{1}(p)=\frac{\frac{m}{1-\frac{\omega_{r}{ }^{2}}{\omega_{0}{ }^{2}}}}{\left(1+\frac{\frac{R^{\prime}}{\omega^{\prime}}}{\omega_{0}^{2}-\omega_{r}{ }^{2}} p+\frac{1}{\omega_{0}^{2}-\omega_{r}{ }^{2}} p^{2}\right)}
\end{aligned}
$$

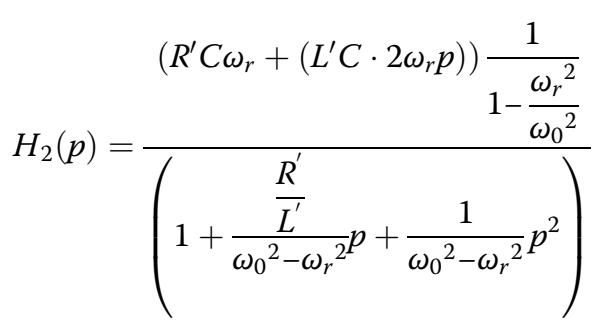

\section{Calculation of power losses in semiconductors}

6.1 Analytical expressions of power losses in semiconductors

The IGBT module is a bidirectional current switching device. It is composed of a bipolar transistor with an insulated gate and an anti-parallel diode which allows bidirectional current (VSI cell case) (Fig. 14 (a)). The IGBT combines the advantages of a bipolar transistor (high voltage, high intensity) and a MOSFET (fast switching).

The diode module added in series with the IGBT module ensures the unidirectional current circulation (CSI cell case) (Fig. 14 (b)).

\subsubsection{Conduction losses}

The equivalent model of an IGBT transistor (Fig. 15 (a)) and the diode (Fig. 15 (b)) during conduction is presented in the following figure:

The analytical expression of the conduction losses can also be expressed in an alternative way in the case when the transistor is in conduction: $[2,14,15]$.

$$
\begin{aligned}
P_{\text {cond.IGBT }}= & \left(V_{C E . s a t} \cdot I_{C . A V G}\right) \\
& +\left(r_{\text {on.IGBT }} \cdot I_{C . r m s}\right)
\end{aligned}
$$

In the same way, the conduction diode losses are expressed as follows: $[2,14,15]$.

$$
P_{\text {cond.D }}=\left(V_{F} \cdot I_{F A V . A V G}\right)+\left(r_{o n . D} I_{F A V . r m s}{ }^{2}\right)
$$

\subsubsection{Switching losses:}

The analytical expressions of the switching losses for IGBT are expressed by $[2,14,15]$ :
$\mathrm{P}_{\text {comm.IGBT }}=\mathrm{f}_{\mathrm{d}} \cdot \frac{\mathrm{V}_{\text {CE }}}{\mathrm{V}_{\text {CE.r }}} \cdot\left(\left(\mathrm{a}_{\text {on }}+\mathrm{a}_{\text {off }}\right) \frac{\mathrm{I}_{\text {C.peak }}{ }^{2}}{4}+\left(\mathrm{b}_{\text {on }}+\mathrm{b}_{\text {off }}\right) \frac{\mathrm{I}_{\text {C.peak }}}{\pi}+\left(\mathrm{c}_{\text {on }}+\mathrm{c}_{\text {off }}\right) \frac{1}{2}\right)$

In the same way, the switching losses of the diode are expressed by: $[2,14,15]$.

- Anti-parallel diode:

$\mathrm{P}_{\text {comm.D }}=\mathrm{f}_{\mathrm{d}} \cdot \frac{\mathrm{V}_{\text {RRM }}}{\mathrm{V}_{\text {RRM.r }}} \cdot\left(\mathrm{a}_{\text {rec }} \frac{\mathrm{I}_{\text {FAV } \cdot \text { peak }}{ }^{2}}{4}+\mathrm{b}_{\text {rec }} \frac{\mathrm{I}_{\text {FAV } \text { peak }}}{\pi}+\mathrm{c}_{\text {rec }} \frac{1}{2}\right)$

- Serial diode (for CSI):

$$
\mathrm{P}_{\text {comm.D }}=\mathrm{f}_{\mathrm{d}} \cdot \mathrm{V}_{\mathrm{r}} \cdot \mathrm{Q}_{\mathrm{rr}}
$$

\subsection{Power losses calculation for VSI cell}

If we take a single-phase AC side of the VSI cell as an example, the both power switches (IGBT module) in the arm (TOP and BOTTOM), switches in a complementary way, and they have the same losses. The Fig. 16 shows the waveform of the current in the IGBT transistor and its anti-parallel diode.

The modulating signal and the injected current for one phase in the VSI cell are expressed as follows:

$$
r_{a^{\prime}}(t)=r_{a^{\prime}, \max } \cdot \sin \left(\omega_{r} t\right)
$$

With $\mathbf{a}^{\prime}$ is a phase reference.

The collector current of IGBT is:

$$
I_{C}(t)=I_{i n j}(t)=\sqrt{2} \cdot I_{i n j} \cdot \sin \left(\omega_{r} t+\phi\right)
$$

The IGBT transistor is conducting in the interval $[\phi$; $\phi+\pi]$, while the antiparallel diode is conducting in the interval $[\phi+\pi ; \phi+2 \pi]$. Therefore, the expressions of the peak, RMS, and AVG values of the IGBT currents and the ant parallel diode current are [11] (see Table 2):

\subsection{Power losses calculation for the CSI cell}

In the same way as for the VSI cell, expressions of the peak, RMS, and AVG values of the IGBT currents and the series diode current for CSI cell are illustrated in Table 3 [11]:

\section{Application and simulation (case study)}

The simulation has been performed with the real parameters of the IGBT module of the manufacturer $\mathrm{ABB}\left(\mathrm{V}_{\mathrm{CE.} . \mathrm{r}}=\right.$ $4.5 \mathrm{KV} / \mathrm{I}_{\mathrm{C} . \mathrm{r}}=1.2 \mathrm{KA}$, ref.: 5SNA1200G450300) and the diode module of the manufacturer SEMIKRON $\left(\mathrm{V}_{\text {RRM.r }}=2.2 \mathrm{KV} /\right.$ 


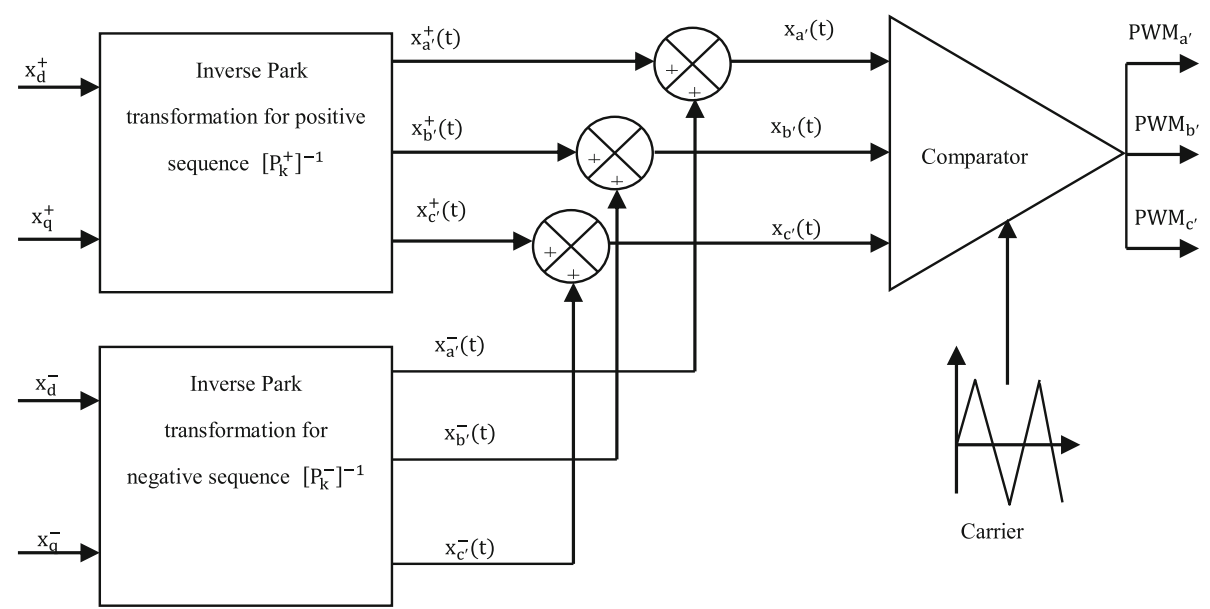

Fig. 11 Generation of three-phase PWM signal

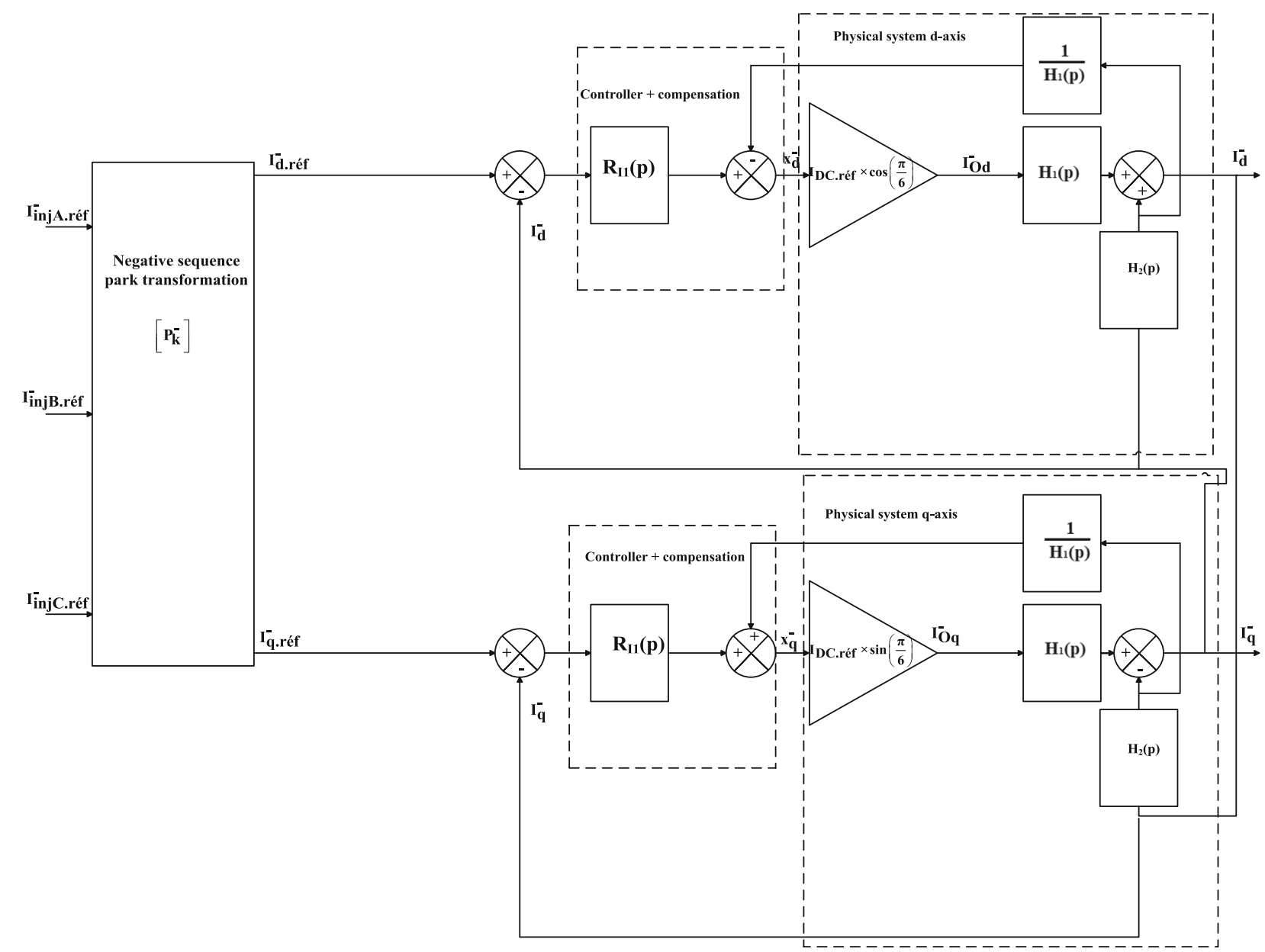

Fig. 12 Diagram control blocks of the injected current negative sequence for CSI cell 


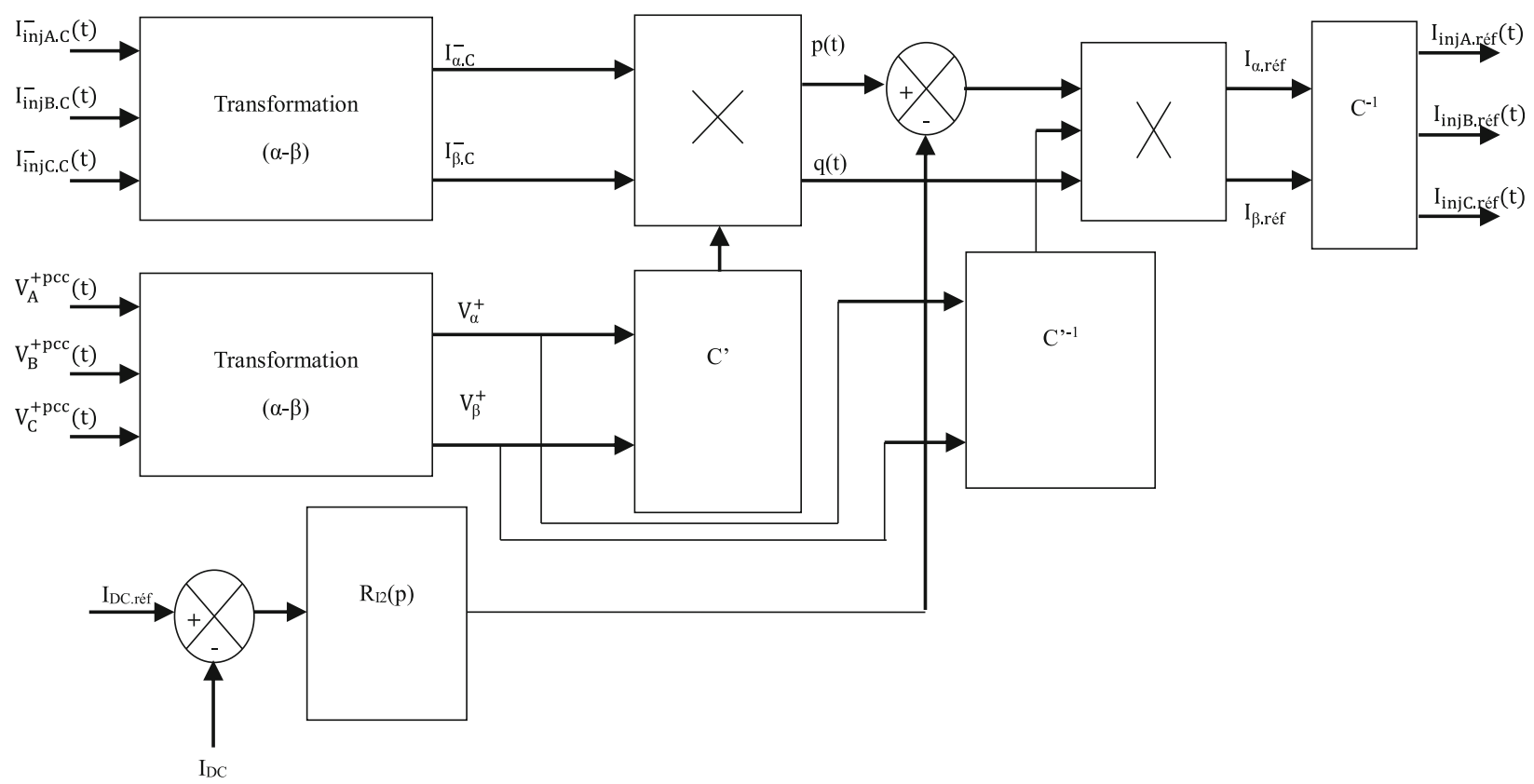

Fig. 13 Diagram control blocks of the voltage $I_{D C}$

$\mathrm{I}_{\mathrm{FAV} . \mathrm{r}}=1.37 \mathrm{KA}$, ref.: SKKE 1200/22 H4). The Table 4 presents the characteristics of these semiconductors.

We choose one substation among others of the new Moroccan HSR as a study case (see Fig. 17). This substation has the following characteristics (see Table 5) [16]. The unbalance (see Fig. 18) caused by this substation exceeds the limit of $2 \%$ imposed by the standard NF EN50160 [17]. Soit is interesting to install an unbalance compensator in this substation.

\subsection{Sizing of the unbalance compensators substation (PK100)}

In this subsection, we calculate the compensator power with a total unbalance compensation for each type of the converter (VSI and CSI). The calculation results are presented in the Table 6.

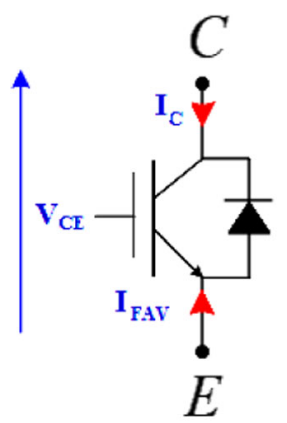

(a)

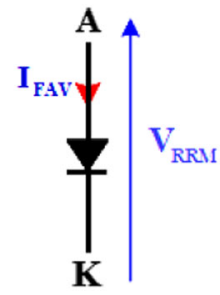

(b)
Fig. 14 a The module of an IGBT with anti-parallel diode. $\mathbf{b}$ The module of the diode in series used in CSI case

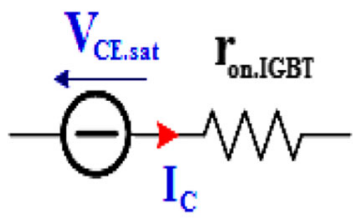

(a)

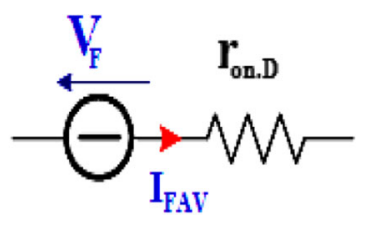

(b)
Table 7 shows the values of the parameters calculated for the power circuit of each cell (VSI and CSI):

Table 8 depicts the values of the controller parameters used for control of each cell (VSI and CSI):

\subsection{Simulation of unbalance compensation}

Figures 19 and 20 show the simulation results of the unbalance factor obtained using static compensators (VSI and CSI):

\subsection{Calculating of power losses in full load}

The Table 9 presents the conduction and switching power losses for each structure of STATCOM (VSI and CSI):

If considering the active power losses in the $\mathrm{AC}$ side filters, and in the DC side storage circuit, the Table 10 presents the global power losses for STATCOM:

Fig. 15 a IGBT model in conduction. b Diode model in conduction 

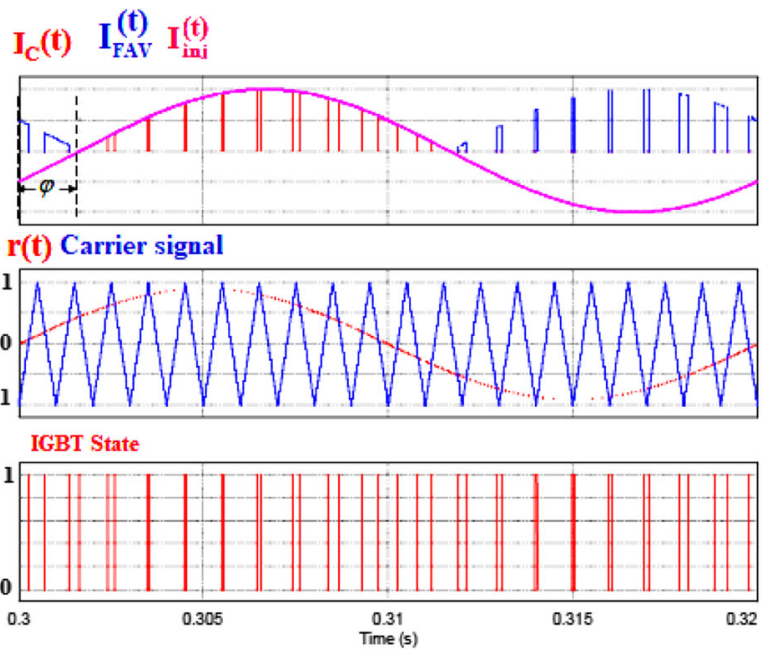

Fig. 16 IGBT and anti-parallel diode currents waveform with sine-triangle PWM modulation

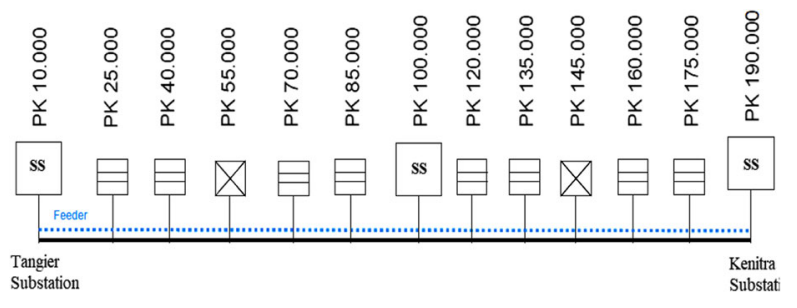

Fig. 17 Distribution schematic of HSR
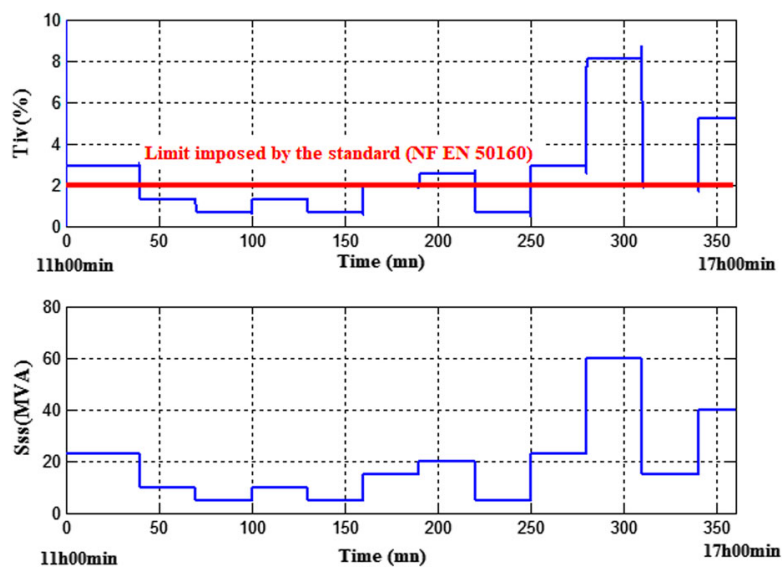

Fig. 18 Unbalance factor and substation power in function of daily railway traffic without STATCOM [16]

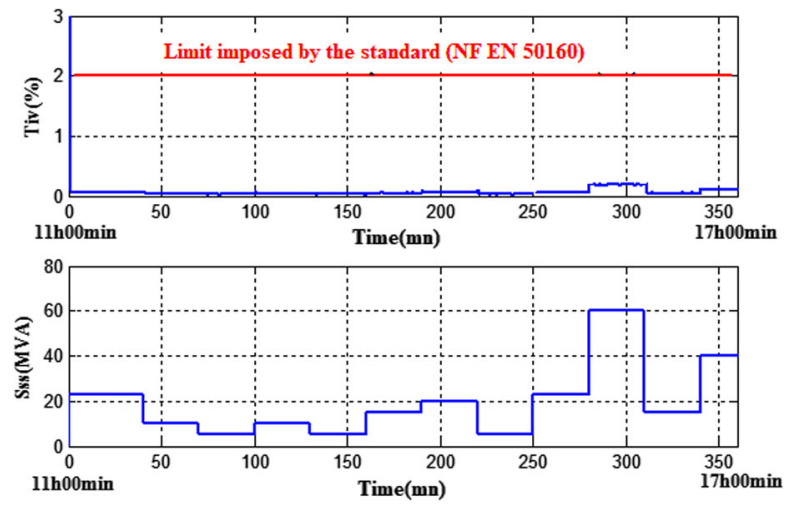

Fig. 19 Unbalance factor in function of daily railway traffic caused by substation Pk100 with VSI_STATCOM

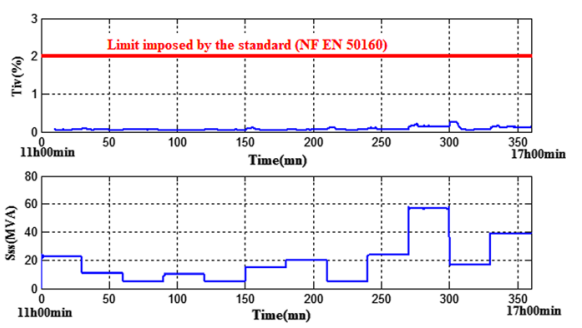

Fig. 20 Unbalance factor in function of daily railway traffic caused by substation Pk100 with CSI-STATCOM

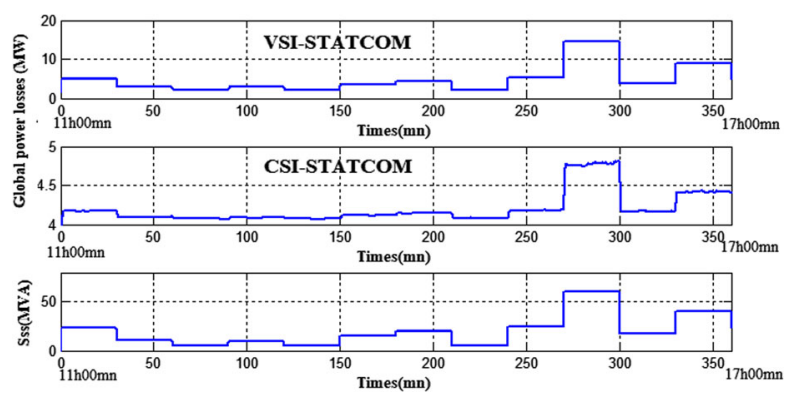

Fig. 21 Global power losses in function of daily railway traffic 
Table 3 Expressions of Peak, RMS, and AVG value of IGBT and antiparallel diode current and voltage (CSI cell)

\begin{tabular}{|c|c|c|c|c|}
\hline & Peak current expression & RMS current expression & AVG current expression & DC Voltage expression \\
\hline IGBT & I DC.réf & $\frac{\mathrm{Dcre} f}{\sqrt{3}}$ & $\frac{\text { ocree f }}{3}$ & $\frac{\sqrt{2} \cdot V_{c}}{3}$ \\
\hline Series diode & I DC.réf & $\frac{\mathrm{dcce} f}{\sqrt{3}}$ & $\frac{\text { loce f }}{3}$ & $\frac{2 \cdot \sqrt{2} \cdot V_{C}}{3}$ \\
\hline
\end{tabular}

Table 4 STATCOM Semiconductors characteristics

\begin{tabular}{|c|c|c|}
\hline Semiconductor & Parameters & Value \\
\hline \multirow[t]{7}{*}{ Transistor (IGBT module) } & $V_{C E \text {. sat }}$ & $3,2 \mathrm{~V}$ \\
\hline & $r_{\text {on. IGBT }}$ & $2,94 \mathrm{~m} \Omega$ \\
\hline & $V_{\text {CE. } r}$ & $4500 \mathrm{~V}$ \\
\hline & $\mathrm{I}_{C . r}$ & $1200 \mathrm{~A}$ \\
\hline & $\left(a_{\text {on }}+a_{\text {off }}\right)$ & 1,2. 10-6 \\
\hline & $\left(b_{o n}+b_{o f f}\right)$ & $6,1 \cdot 10-3$ \\
\hline & $\left(c_{o n}+c_{o f f}\right)$ & 1,08 \\
\hline \multirow[t]{7}{*}{ Anti-parallel Diode (IGBT module) } & $V_{F}$ & $3,25 \mathrm{~V}$ \\
\hline & $r_{\text {on. }} \mathrm{D}$ & $2,98 \mathrm{~m} \Omega$ \\
\hline & $V_{\text {RRM. } r}$ & $4500 \mathrm{~V}$ \\
\hline & $I_{\text {FAV } . r}$ & $1200 \mathrm{~A}$ \\
\hline & $\mathrm{a}_{\mathrm{rec}}$ & $-5,25 \cdot 10-7$ \\
\hline & $b_{\text {rec }}$ & $2,61.10-3$ \\
\hline & $c_{\text {rec }}$ & 375. 10-3 \\
\hline \multirow[t]{6}{*}{ Series Diode (Diode module) } & $V_{F}$ & $0,82 \mathrm{~V}$ \\
\hline & $r_{\text {on. }} \mathrm{D}$ & $0,858 \mathrm{~m} \Omega$ \\
\hline & $\mathrm{Q}_{\mathrm{rr}}$ & $700 \mu \mathrm{C}$ \\
\hline & $V_{r}$ & $100 \mathrm{~V}$ \\
\hline & $V_{\text {RRM. } r}$ & $2200 \mathrm{~V}$ \\
\hline & $I_{F A V . r}$ & $1370 \mathrm{~A}$ \\
\hline
\end{tabular}

Table 5 Substation characteristics of study case

\begin{tabular}{|c|c|}
\hline Characteristics & Value \\
\hline Transformer rated power & $60 \mathrm{MVA}$ \\
\hline Transformer primary rated voltage & $225 \mathrm{KV}$ \\
\hline $\begin{array}{l}\text { Transformer secondary rated } \\
\text { voltage }\end{array}$ & $2^{*} 25 \mathrm{KV}-50 \mathrm{~Hz}$ \\
\hline Connection & Tow-phases \\
\hline secondary situation & Mid-point \\
\hline Kilometric point of substation & Pk100 (100 km) \\
\hline $\begin{array}{l}\text { Distribution schematic of High } \\
\text { speed substations }\end{array}$ & Figure 17 \\
\hline $\begin{array}{l}\text { Unbalance factor in function of } \\
\text { daily railway traffic between } \\
11 \mathrm{~h} 00 \mathrm{mn} \text { and } 17 \mathrm{~h} 00 \mathrm{mn}\end{array}$ & Figure 18 \\
\hline $\begin{array}{l}\text { Power grid High voltage line } \\
(225 \mathrm{KV})\end{array}$ & $\begin{array}{l}\text { Short-circuit power: } \mathrm{S}_{c c}=800 \mathrm{MVA} \text {, } \\
\text { Line parameters: } \mathrm{R}_{\text {line }}(\Omega / \mathrm{Km})= \\
0.129 \text { and } \mathrm{L}_{\text {line }}(\mathrm{mH} / \mathrm{Km})=1.366\end{array}$ \\
\hline
\end{tabular}

\subsection{Simulation of power losses in dynamic power variation}

Figure 21 shows the dynamic evolution of the global power losses according to the variation of the power consumed by the substation during railway traffic.

\subsection{Discussion and evaluation of the results}

In sizing terms, the calculation results in Table 10 show that the unbalance compensator with a voltage source inverter (VSI) needs up to 24 converter cells, but the one with a current source inverter (CSI) needs only up to 9 converter cells. This is the advantage of STATCOM with CSI cells; which is the congestion in the railway substation, and the reduced costs.

Figures 19 and 20 show that the STATCOM with VSI cell or CSI cell allow to control the unbalance factor according to the standards $\left(\mathrm{T}_{\mathrm{iv}}<2 \%\right)$.

In terms of power losses and efficiency, the calculation results in (Table 10) show that, the compensator based on CSI (4.75 MW, 92.56\%) is more optimal than the one based on VSI (14.52 MW, 80.51\%), in steady state with full load condition. In addition, Fig. 21 demonstrates that the STATCOM with CSI cells has less loss than the one with VSI in dynamic daily railway traffic. Thus, we conclude that the unbalance compensation with CSI cells is an optimal solution for railway operator.

\section{Conclusion}

According to the sizing procedure described in this paper, the use of STATCOM compensator is much more required when daily railway traffic reaches a certain value, especially in rush hours. This compensator implies a big investment for the railway operator. For this reason, the designer engineering office tries to choose the optimal solution in terms of cost and efficiency. The obtained results show that the VSISTATCOM has lower efficiency then the CSI-STATCOM (80,51\% VS 92.65\%) with full load (rated conditions). The CSI-STATCOM presents a reduced number of converter cells compared to the VSI-STATCOM which reduces the size and the cost of the compensator while keeping the unbalance factor lower than the limit of $\mathbf{2 \%}$ imposed by the standard. We conclude so that the STATCOM based on CSI is an optimal solution in high power compensation.

The experimental validation for this comparative study makes the objective of a second paper. 
Table 6 Sizing results for unbalance compensator

\begin{tabular}{llll}
\hline & Compensation power $S_{c}$ & Cell power $S_{\text {cel }}$ & Number of cell \\
\hline VSI_STATCOM & 60MVA & 2544MVA & 24 \\
CSI_STATCOM & 60MVA & $7,24 \mathrm{MVA}$ & 9 \\
\hline
\end{tabular}

Table 7 STATCOM power circuit parameters

\begin{tabular}{|c|c|c|c|}
\hline & AC filter & DC circuit & Transformer ratio \\
\hline VSI cell & $\mathrm{L}=2 \mathrm{mH}(\mathrm{R}=0,12 \Omega)$ & $\begin{array}{l}\mathrm{C}_{\mathrm{dc}}=11,31 \mathrm{mF} \\
\mathrm{V}_{\mathrm{dc}}=4,5 \mathrm{KV}\end{array}$ & $m=8153 \cdot 10-3$ \\
\hline CSI cell & $\mathrm{L}^{\prime}=1 \mathrm{mH}\left(\mathrm{R}^{\prime}=6 \mathrm{~m} \Omega\right), \mathrm{C}=827 \mu \mathrm{F}$ & $\begin{array}{l}\mathrm{L}_{\mathrm{dc}}=0.378 \mathrm{H} \quad\left(\mathrm{R}_{\mathrm{dc}}=0,27 \Omega\right) \\
\mathrm{I}_{\mathrm{dc}}=1,2 \mathrm{KA}\end{array}$ & $m=20,092 \cdot 10-3$ \\
\hline
\end{tabular}

Table 8 Controller parameters

\begin{tabular}{llll}
\hline & Injected current controller & DC circuit controller & Switching frequency \\
\hline VSI cell & $T_{1}=0,1 \mathrm{~S}, \mathrm{~K}_{\mathrm{I}}=7359 \cdot 103$ & $T_{\mathrm{v}}=14,14 \mathrm{~ms}, \mathrm{~K}_{\mathrm{v}}=1,8 \cdot 103$ & $10 \mathrm{Khz}$ \\
CSI cell & $\mathrm{T}_{\mathrm{P}^{\prime}}=5,4 \mathrm{\mu S}, \mathrm{Td}=0,16 \mathrm{~S} \mathrm{K \textrm {P } ^ { \prime }}=7,4$ & $\mathrm{~T}_{\mathrm{IDC}}=14,14 \mathrm{~ms}, \mathrm{~K}_{\mathrm{IDC}}=16,03 \cdot 103$ & $10 \mathrm{Khz}$ \\
\hline
\end{tabular}

Table 9 Power losses converter STATCOM

\begin{tabular}{lllll}
\hline STATCOM Converter & Conduction Power losses (MW) & switching Power losses (MW) & Total Power losses in converter (MW) & Efficiency (\%) \\
\hline 24 VSI cell & 0,417 & 8414 & 8832 & 87,168 \\
9 CSI cell & 0,179 & 0,95 & 1129 & 98,15 \\
\hline
\end{tabular}

Table 10 Global power losses for STATCOM

\begin{tabular}{lllll} 
& $\begin{array}{l}\text { Active power losses in the filter, AC and DC side } \\
\text { (MW) }\end{array}$ & $\begin{array}{l}\text { Power losses converter } \\
\text { (MW) }\end{array}$ & $\begin{array}{l}\text { Global Power losses } \\
(\text { MW })\end{array}$ & $\begin{array}{l}\text { Global Efficiency } \\
(\%)\end{array}$ \\
\hline VSI_STATCOM & 5691 & 8832 & 14,523 & 80,512 \\
CSI_E & 3629 & 1129 & 4758 & 92,652 \\
STATCOM & & & & \\
\hline
\end{tabular}




\section{Nomenclatures}

$\mathrm{a}, \mathrm{b}, \mathrm{c}$ phase indexes

,+- positive and negative sequence indexes

$\mathrm{S}_{\mathrm{C}}$ Compensator apparent power

$\mathrm{S}_{\mathrm{cc}}$ Short-circuit apparent power

$\mathrm{S}_{\mathrm{ss}}$ Apparent power consumed by substation

Sc.total Apparent power for total compensation

Sc.partialApparent power for partial compensation

$\mathrm{S}_{\text {cell }}$ converter cell apparent power

$\mathrm{P}_{\text {cond }}$ Conduction losses

$\mathrm{P}_{\text {comm }}$ Switching losses

V HVline-ground rated voltages

$\mathrm{V}^{\mathrm{pcc}} \mathrm{HV}$ line-ground voltages in PCC

UHV line-line RMS voltage

$\mathrm{V}_{\text {DC.ref }} \mathrm{DC}$ voltage set-point for VSI

$\Delta \mathrm{V}_{\mathrm{DC}}$ voltage ripple in DC side for VSI

$\mathrm{V}_{\mathrm{CE}} \mathrm{IGBT}$ collector-emitter voltage

$\mathrm{V}_{\mathrm{F}}$ Diode forward voltage

VLine-ground in filter capacity for CSI

$\mathrm{I}_{\mathrm{sw}}$ and $\mathrm{V}_{\mathrm{sw}}$ current and voltage of the semiconductor switch

$\mathrm{I}_{\mathrm{T}}$ Current consumed by train

iReturn current to substation

$\mathrm{I}_{\mathrm{ss}}$ Current consumed by substation

IHV line phase current

$\mathrm{I}_{\text {inj }}$ injected current by compensator

$\mathrm{I}_{\mathrm{C}} \mathrm{IGBT}$ collector current

$\mathrm{I}_{\mathrm{FAV}}$ diode current

$\Delta \mathrm{I}_{\text {inj }}$ injected current ripple in $\mathrm{AC}$ side inverter for VSI

$\mathrm{T}_{\mathrm{iv}}$ voltage unbalance factor

mtransformer ratio

$\mathrm{N}_{\mathrm{VSI}}$ number of voltage source inverter cell

$\mathrm{N}_{\text {CSI }}$ number of current source inverter cell

$\mathrm{f}_{\mathrm{d}}$ switching frequency

$\omega_{0}$ Natural frequency of RLC filter for CSI

$\omega_{\text {rpower grid pulsation }}$

$\mathrm{Z}_{\mathrm{CC}}$ Line impedance in PCC

$\mathrm{r}_{\text {on }}$ dynamic resistance diode

\section{Acknowledgements}

The authors would like to thank the anonymous reviewers for their helpful and constructive comments that greatly contributed to improving the final version of the paper. They would also like to thank the Editors for their generous comments and support during the review process.

\section{Authors' contributions}

$A B$, and JB performed the detailed design of the compensator cell sizing (VSI and $(\mathrm{CSI})$, as well as the calculation of the semiconductors power losses. ME, $\mathrm{BH}$, and LE corresponding, engaged in modifying the paper and submitted it to the PCMP. SM, MT and YM checked the grammar and writing of the paper. All authors read and approved the final manuscript.

\section{Funding}

The work is not supported by any funding agency. This is the authors own research work.

\section{Availability of data and materials}

Data sharing not applicable to this article as no datasets were generated or analyzed during the current study.

\section{Competing interests}

The authors declare that they have no competing interests.

\begin{abstract}
Author details
${ }^{1}$ Laboratory Renewable energy, embedded system and information processing, National School of Applied Sciences, University of Mohammed I, Oujda, Morocco. ${ }^{2}$ Laboratory of Electrical Engineering and Maintenance,

Higher School of Technology, University of Mohammed I, Oujda, Morocco.
\end{abstract}

Received: 4 October 2019 Accepted: 16 December 2019

Published online: 03 February 2020

References

1. Kuo, H. Y., \& Chen, T. H. (1998). Rigorous evaluation of the voltage unbalance due to high-speed railway demands. IEEE Transactions on Vehicular Technology, 47(4), 1385-1389.

2. Raimondo, G. (2012). Power quality improvements in $25 \mathrm{KV}-50 \mathrm{~Hz}$ railway substations based on chopper controlled impedances. Thesis in Electrical Engineering in Toulouse University (pp. 1-122).

3. Grunbaum, R. (2007). FACTS for dynamic load balancing and voltage support in rail traction. Proceedings of 12th Conference of Power Electronic (pp. 1-10).

4. Grunbaum, R. (2007). FACTS for power quality improvement in grids feeding high speed rail traction. Electric Machines \& Drives IEEE International Conference (pp. 618-623).

5. Ghorbani, A., Ebrahimi, S. Y., \& Ghorbani, M. (2017). Active power based distance protection scheme in the presence of series compensators. Prot Control Mod Power Syst, 2(1), 1-13.

6. Mishra, S. K., \& Tripathy, L. N. (2019). A critical fault detection analysis \& fault time in a UPFC transmission line. Prot Control Mod Power Syst, 4(1), 1-10.

7. Yong, L. Q., Ran, L. X., Ju, L. X., Bo, L., DeSheng, C., \& Yuan, P. (2011). Impact of negative sequence current of traction load on the grid running state. The International Conference on Advanced Power System Automation and Protection (pp. 879-883).

8. Benslimane, A., Bouchnaif, J., Azizi, M., \& Grari, K. (2013). Study of a STATCOM used for unbalanced current compensation caused by a high speed railway (HSR) sub-station. IEEE conference, proceedings of 2013 international renewable and sustainable energy conference (IRSEC) (pp. 441-446).

9. Zegnoun, S. A., Tandjaoui, M. N., Djebbar, M., Benachaiba, C., \& Mazari, B. (2019). Power quality enhancement by using D-FACTS systems applied to distributed generation. Int J Power Electron Drive Syst, 10(1), 330-341.

10. Benslimane, A., Bouchnaif, J., Azizi, M., \& Grari, K. (2016). An experimental study of the unbalance compensation by voltage source inverter based STATCOM. Int J Power Electron Drive Syst, 7(1), 45-55.

11. Bouchard, R. P., \& Guy, O. (1999). Electrotechnique. Book, Edition 2, Presses internationals polytechnic ISBN 2-553-00720-5.

12. Benslimane, A., Bouchnaif, J., \& Azizi, M. (2013). Comparative study between (CSI based STATCOM and VSI based STATCOM) used for current unbalance compensation. Int J Eng Res Technol, 2(12), 1828-1835.

13. Zhengming, L., Li, W., \& Pan, T. (2016). An optimized compensation strategy of DVR for micro-grid voltage sag. Prot Control Mod Power Syst, 1(1), 1-8.

14. Wang, J., Yuan, X., Zhang, Y., Dagan, K J., Liu, X., Drury, D., \& Mellor, P. (2017). Analytical averaged loss model of three-phase T-type STATCOM with virtual zero level modulation. IEEE Energy Conversion Congress and Exposition (ECCE) (pp. 5355-5361).

15. Rolle, B., \& Sawodny, O. (2018). Analytical voltage-source inverter current and conduction loss models for EV power train simulations. International Federation of Automatic Control, 51-31, 479-484 PapersOnLine.

16. Group CEGELEC-SYSTRA-FG. (2016). Design and realization of the electrical central sub-station and the catenary power supply installations (marché de conception et de realisation du central sous-station electrique et des installations d'alimentation de la catenaire). In Study \& sizing report for High speed line, ONCF (national office of Moroccan railway), version. 3 (pp. 1-118).

17. The Technical Union of Electricity (UTE) (2011). Voltage characteristics of electricity supplied by public electricity networks. European standards EN50160. 